\title{
Profil Pasien Rinosinusitis Kronik di Poliklinik THT-KL RSUP DR.M.Djamil Padang
}

\author{
Hesty Trihastuti ${ }^{1}$, Bestari Jaka Budiman², Edison ${ }^{3}$
}

\begin{abstract}
Abstrak
Rinosinusitis kronik adalah inflamasi kronik pada mukosa hidung dan sinus paranasal yang sering terjadi, tetapi belum ada data mengenai profil pasien rinosinusitis kronik di RSUP Dr.M.Djamil Padang. Penelitian ini merupakan penelitian deskriptif dengan mengambil data rekam medis THT-KL RSUP Dr.M.Djamil periode 1 Januari - 31 Desember 2012 dengan metode total sampling. Terdapat 63 kasus rinosinusitis kronik di poliklinik THT-KL RSUP Dr.M.Djamil Padang periode 1 Januari - 31 Desember 2012. Kasus rinosinusitis kronik paling banyak terjadi pada kelompok usia 46 - 55 tahun (22,22\%) dan banyak terjadi pada perempuan (60,32\%). Berdasarkan tanda dan gejala yang ditemukan paling banyak adalah deviasi septum $(41,27 \%)$. Gejala klinik paling banyak adalah hidung tersumbat (88,89\%). Berdasarkan pemeriksaan rinoskopi anterior dan nasoendoskopi ditemukan kelainan pada kavum nasi, konka inferior, konka media, dan sekret. Disimpulkan bahwa rinosinusitis kronik banyak terjadi pada usia dewasa, jenis kelamin perempuan, tanda dan gejala yang ditemukan deviasi septum, gejala berupa hidung tersumbat, serta ditemukan kelainan berdasarkan pemeriksaan rinoskopi anterior dan nasoendoskopi.
\end{abstract}

Kata kunci: rinosinusitis kronik, pemeriksaan rinoskopi anterior, pemeriksaan nasoendoskopi

\section{Abstract}

Chronic rhinosinusitis is a common chronic inflammation of the nose and paranasal sinuses mucosa, but there is no data about profile of chronic rhinosinusitis patients at ENT clinic Dr.M.Djamil general hospital Padang. This research uses descriptive method by taking the data from the medical records at ENT clinic of Dr.M.Djamil general hospital during 1 January - 31 December 2012 with the method is total sampling. There are 63 chronic rhinosinusitis cases at ENT clinic Dr.M.Djamil Padang general hospital during 1 January - 31 December 2012. Most cases of chronic rhinosinusitis occurred in the age group 46 - 55 years old (22.22\%) and higher in female (60.32\%). The most sign and symptom finding is septal deviation (41.27\%). The most clinical symptom is nasal obstruction (88.89\%). From anterior rhinoscopy and nasoendoscopy examination, there are founded abnormalility of nasal cavity, inferior turbinate, middle turbinate, and nasal discharge. The conclusion is chronic rhinosinusitis often happened at adult ages, female, septal deviation as the most sign and symptom finding, nasal obstruction as the clinical symptom, and abnormal findings from anterior rhinoscopy and nasal endoscopy examination.

Keywords: chronic rhinosinusitis, anterior rhinoscopy examination, nasal endoscopy examination

Affiliasi penulis: 1. Pendidikan Dokter FK UNAND (Fakultas Kedokteran Universitas Andalas Padang), 2. Bagian THT-KL FK UNAND, 3. Bagian IImu Kesehatan Masyarakat FK UNAND

Korespondensi: Hesty Trihastuti, email : hesty_tht@yahoo.co.id Telp: (0751) 72645

\section{PENDAHULUAN}

Rinosinusitis merupakan suatu penyakit peradangan mukosa yang melapisi hidung dan sinus paranasalis. Rinosinusitis adalah istilah yang lebih tepat karena sinusitis jarang tanpa didahului rinitis dan 
tanpa melibatkan inflamasi mukosa hidung. Inflamasi sering bermula akibat infeksi bakteri, virus, jamur, infeksi dari gigi, serta dapat pula terjadi akibat tumor dan fraktur. Berdasarkan konsensus tahun 2004, rinosinusitis dibagi atas 3 kriteria, yaitu rinosinusitis akut yang berlangsung selama empat minggu, rinosinusitis sub akut yang berlangsung antara empat sampai dua belas minggu, dan rinosinusitis kronik yang berlangsung lebih dari dua belas minggu. ${ }^{1-3}$

Rinosinusitis kronik memiliki prevalensi yang tinggi di masyarakat. Di Eropa diperkirakan sekitar 10 - 15\% menderita penyakit rinosinusitis. Sebanyak $14 \%$ penduduk Amerika, paling sedikit pernah mengalami episode rinosinusitis dan sekitar 15\% diperkirakan menderita rinosinusitis kronik. Data dari respiratory surveillance program menunjukkan bahwa rinosinusitis paling banyak ditemukan pada etnis kulit putih. $^{4}$

Berdasarkan jenis kelamin, penyakit rinosinusitis kronik lebih banyak terjadi pada perempuan daripada laki - laki dengan perbandingan $2: 1$ dan sering pada usia 25 - 64 tahun. Rinosinusitis kronik dapat disebabkan karena faktor non polip nasi dan faktor polip nasi. Oleh karena itu, perlu dilakukan pemeriksaan klinik, seperti pemeriksaan rinoskopi anterior dan nasoendoskopi untuk menentukan adanya polip nasi di meatus media. ${ }^{4,5}$

Menurut Task Force yang dibentuk oleh American Academy of Otolaryngic Allergy ( $A A O A)$ dan American Rhinologic Society (ARS), rinosinusitis kronis dapat ditegakkan berdasarkan dua gejala mayor atau lebih, atau satu gejala mayor ditambah dua gejala minor. Berdasarkan penelitian dengan menggunakan 22 sampel didapatkan gejala yang paling sering pada pasien rinosinusitis kronis antara lain hidung tersumbat (100\%), ingus purulen (95,5\%), nyeri pada wajah $(91 \%)$, fatigue $(63,6 \%)$, gangguan penghidu $(59,1 \%)$, dan gangguan tidur $(54,5 \%){ }^{6}$

Tingginya angka kejadian rino-sinusitis kronik dan belum adanya data mengenai profil pasien rinosinusitis kronik di RSUP Dr.M.Djamil Padang membuat peneliti tertarik untuk melakukan penelitian lebih lanjut mengenai rinosinusitis kronis berdasarkan angka kejadian, usia, jenis kelamin, tanda dan gejala yang ditemukan, gejala klinik, pemeriksaan rinoskopi anterior, dan pemeriksaan nasoendoskopi sehingga akan didapatkan data dasar dari kasus rinosinusitis kronis.

Tujuan penelitian ini adalah untuk mengetahui profil pasien rinosinusitis kronis di Poliklinik THT-KL RSUP Dr.M.Djamil Padang pada periode 1 Januari - 31 Desember 2012. Secara khusus, penelitian ini bertujuan untuk mengetahui insiden rinosinusitis kronis, sebaran pasien rinosinusitis kronis menurut kelompok umur, jenis kelamin, tanda dan gejala yang ditemukan, gejala klinik, pemeriksaan rinoskopi anterior, dan pemeriksaan nasoendoskopi.

\section{METODE}

Jenis penelitian ini bersifat deskriptif dengan mengambil data dari rekam medis pasien poliklinik THT-KL RSUP Dr.M.Djamil Padang periode 1 Januari - 31 Desember 2012. Pengambilan data penelitian dilakukan pada bulan Maret 2013 yang dilakukan di rekam medik THT-KL RSUP Dr.M.Djamil Padang.

Populasi penelitian adalah semua pasien rinosinusitis kronik yang berobat di poliklinik THT-KL RSUP Dr.M.Djamil Padang pada periode 1 Januari 31 Desember 2012 yang dijadikan subjek penelitian. Kriteria inklusi penelitian adalah pasien rinosinusitis kronik yang berobat ke poliklinik bagian THT-KL RSUP Dr.M.Djamil Padang sesuai dengan data rekam medik pasien rinosinusitis kronik pada periode 1 Januari - 31 Desember 2012. Kriteria eksklusi adalah pasien rinosinusitis kronik yang disebabkan oleh infeksi jamur dan/atau infeksi gigi (dentogen).

Variabel dan definisi operasional penelitian adalah rinosinusitis kronik, usia, jenis kelamin, tanda dan gejala yang ditemukan, gejala klinik, pemeriksaan rinoskopi anterior, dan pemeriksaan nasoendoskopi. Data penelitian ini adalah data sekunder yang diambil dari data rekam medik di Poliklinik THT-KL RSUP Dr.M.Djamil Padang.

Pencatatan dilakukan berdasarkan umur, jenis kelamin, tanda dan gejala yang ditemukan, gejala klinik, pemeriksaan rinoskopi anterior, dan pemeriksaan nasoendoskopi. Pengolahan data dilakukan secara manual, disusun dalam bentuk tabel, dan dianalisis secara deskriptif untuk menarik kesimpulan. 
HASIL

Tabel 1. Distribusi jumlah pasien rinosinusitis kronik berdasarkan kelompok usia

\begin{tabular}{lcc}
\hline Kelompok Usia & Jumlah & $\%$ \\
\hline Usia bayi dan anak-anak (0 - & 6 & 9,52 \\
14 tahun) & & \\
$\begin{array}{l}\text { Usia muda dan dewasa (15 - } \\
49 \text { tahun) }\end{array}$ & 39 & 61,90 \\
Usia tua ( $\geq 50$ tahun) & 18 & 28,57 \\
\hline Total & $\mathbf{6 3}$ & $\mathbf{1 0 0}$ \\
\hline
\end{tabular}

Tabel 1 menunjukkan penderita rinosinusitis kronik terbanyak pada kelompok usia muda dan dewasa (15 - 49 tahun), yaitu sebanyak 39 kasus $(61,90 \%)$.

Tabel 2. Distribusi jumlah pasien rinosinusitis kronik berdasarkan jenis kelamin

\begin{tabular}{lcc}
\hline Jenis Kelamin & Jumlah & $\%$ \\
\hline Laki-laki & 25 & 39,68 \\
Perempuan & 38 & 60,32 \\
\hline Total & 63 & 100 \\
\hline
\end{tabular}

Tabel 2 menunjukkan pasien rinosinusitis kronik banyak terjadi pada perempuan, yaitu sebanyak 38 kasus $(60,32 \%)$ dibandingkan dengan laki-laki, yaitu sebanyak 25 kasus (39,68\%).

Tabel 3. Distribusi kasus rinosinusitis kronik berdasarkan tanda dan gejala yang ditemukan

\begin{tabular}{lcc}
\hline $\begin{array}{l}\text { Tanda dan Gejala yang } \\
\text { Ditemukan }\end{array}$ & Jumlah & $\%$ \\
\hline Deviasi septum & 26 & 41,27 \\
Hipertrofi adenoid & 2 & 3,17 \\
Rhinitis alergi & 7 & 11,11 \\
Polip nasi & 11 & 17,46 \\
Idiopatik & 19 & 30,16 \\
\hline
\end{tabular}

Tabel 3 menunjukkan kasus rinosinusitis kronik banyak disebabkan oleh deviasi septum, yaitu sebanyak 26 kasus (41,27\%).

Tabel 4. Distribusi kasus rinosinusitis kronik berdasarkan gejala klinik

\begin{tabular}{lcc}
\hline Gejala Klinik & Jumlah & $\%$ \\
\hline Pilek & 45 & 71,43 \\
Hidung tersumbat & 56 & 88,89 \\
Bersin-bersin $\geq 5$ kali & 3 & 4,76 \\
Hidung berbau & 4 & 6,35 \\
Nyeri kepala & 18 & 28,57 \\
Nyeri / berat pada wajah & 12 & 19,05 \\
Hiposmia & 12 & 19,05 \\
Ingus di tenggorok & 43 & 68,25 \\
Hidung berdarah & 5 & 7,94 \\
\hline
\end{tabular}

Tabel 4 menunjukkan gejala klinik yang banyak dirasakan oleh pasien rinosinusitis kronik adalah hidung tersumbat, yaitu sebanyak 56 kasus $(88,89 \%)$.

Tabel 5. Distribusi pasien rinosinusitis kronik berdasarkan hasil pemeriksaan rinoskopi anterior

\begin{tabular}{|c|c|c|c|c|c|c|}
\hline Pemeriksaan & & & & & KND & \\
\hline $\begin{array}{l}\text { Rinoskopi } \\
\text { Anterior }\end{array}$ & KND & $\%$ & KNS & $\%$ & $\begin{array}{c}\& \\
\text { KNS }\end{array}$ & $\%$ \\
\hline \multicolumn{7}{|l|}{ Kavum Nasi : } \\
\hline Sempit & 43 & 68,25 & 51 & 80,95 & 94 & 74,60 \\
\hline Lapang & 20 & 31,75 & 12 & 19,05 & 32 & 25,40 \\
\hline Konka Inferior : & & & & & & \multirow{2}{*}{8,73} \\
\hline Hipertrofi & 6 & 9,52 & 5 & 7,94 & 11 & \\
\hline Eutrofi & 29 & 46,03 & 20 & 31,75 & 49 & \multirow{2}{*}{38,89} \\
\hline Udem & 27 & 42,86 & 35 & 55,56 & 62 & \\
\hline Sukar dinilai & 1 & 1,59 & 3 & 4,76 & 4 & $\begin{array}{l}49,21 \\
3,17\end{array}$ \\
\hline \multicolumn{7}{|l|}{ Konka Media : } \\
\hline Hipertrofi & 2 & 3,17 & 0 & 0 & 2 & 1,59 \\
\hline Eutroti & 23 & 36,50 & 19 & 30,16 & 42 & 33,33 \\
\hline Udem & 6 & 9,52 & 4 & 6,35 & 10 & 7,94 \\
\hline sukar dinilal & 23 & 36,50 & 32 & 50,79 & 55 & 43,65 \\
\hline Paradoks & 2 & 3,17 & 0 & 0 & 2 & 1,59 \\
\hline polip & 7 & 11,11 & 8 & 12,70 & 15 & 11,90 \\
\hline \multicolumn{7}{|l|}{ Sekret : } \\
\hline$(+)$ & 49 & 77,78 & 47 & 74,60 & 96 & 76,19 \\
\hline$(-)$ & 14 & 22,22 & 16 & 25,40 & 30 & 23,81 \\
\hline \multicolumn{7}{|l|}{ Deviasi Septum } \\
\hline $\begin{array}{l}: \\
(+)\end{array}$ & 22 & 34,92 & 23 & 36,51 & 45 & 35,71 \\
\hline $\begin{array}{l}(+) \\
(-)\end{array}$ & 41 & 65,08 & 40 & 63,49 & 81 & 64,29 \\
\hline Total & 63 & 100 & 63 & 100 & 126 & 100 \\
\hline
\end{tabular}


Tabel 5 menunjukkan hasil pemeriksaan rinoskopi anterior pada 63 pasien dengan temuan kavum nasi sempit 94 kasus (74,60\%), konka inferior udem 62 kasus (49,21\%), konka media sukar dinilai 55 kasus (43,65\%), sekret positif 96 kasus $(76,19 \%)$, dan tidak ada deviasi septum 81 kasus $(64,29 \%)$.

Tabel 6. Distribusi pasien rinosinusitis kronik berdasarkan hasil pemeriksaan nasoendoskopi

\begin{tabular}{|c|c|c|c|c|c|c|}
\hline \multirow[b]{2}{*}{$\begin{array}{l}\text { Pemeriksaan } \\
\text { Nasoendoskopi }\end{array}$} & \multirow[b]{2}{*}{ KND } & \multirow[b]{2}{*}{$\%$} & \multirow[b]{2}{*}{ KNS } & \multicolumn{3}{|c|}{ KND } \\
\hline & & & & $\%$ & $\begin{array}{c}\& \\
\text { KNS }\end{array}$ & $\%$ \\
\hline \multicolumn{7}{|l|}{ Kavum Nasi : } \\
\hline Sempit & 16 & 64 & 17 & 68 & 33 & 66 \\
\hline Lapang & 9 & 36 & 8 & 32 & 17 & 34 \\
\hline \multicolumn{7}{|l|}{ Konka Inferior : } \\
\hline Hipertrofi & 4 & 16 & 3 & 12 & 7 & 14 \\
\hline $\begin{array}{l}\text { Eutrori } \\
\text { Udem }\end{array}$ & 12 & 48 & 11 & 44 & 23 & 46 \\
\hline Udem & 8 & 32 & 9 & 36 & 17 & 34 \\
\hline $\begin{array}{l}\text { Tertutup massa } \\
\text { polip }\end{array}$ & 1 & 4 & 2 & 8 & 3 & 6 \\
\hline \multicolumn{7}{|l|}{ Warna Konka } \\
\hline Inferior: & 3 & 12 & 5 & 20 & 8 & 16 \\
\hline Pucat & 20 & 80 & 19 & 76 & 39 & 78 \\
\hline $\begin{array}{l}\text { Meran muda } \\
\text { Hineremis }\end{array}$ & 1 & 4 & 0 & 0 & 1 & 2 \\
\hline miperems & 0 & 0 & 1 & 4 & 1 & 2 \\
\hline $\begin{array}{l}\text { Livid } \\
\text { Sukar dinilai }\end{array}$ & 1 & 4 & 0 & 0 & 1 & 2 \\
\hline \multicolumn{7}{|l|}{ Konka Media : } \\
\hline Hipertrofi & 1 & 4 & 0 & 0 & 1 & 2 \\
\hline Eutrofi & 14 & 56 & 18 & 72 & 32 & 64 \\
\hline Udem & 5 & 20 & 3 & 12 & 8 & 16 \\
\hline Sukar dinilai & 3 & 12 & 4 & 16 & 7 & 14 \\
\hline Paradoks & 2 & 8 & 0 & 0 & 2 & 4 \\
\hline \multicolumn{7}{|l|}{ Meatus media: } \\
\hline Terbuka & 15 & 60 & 15 & 60 & 30 & 60 \\
\hline Tertutup & 10 & 40 & 10 & 40 & 20 & 40 \\
\hline \multicolumn{7}{|l|}{ Sekret : } \\
\hline$(+)$ & 19 & 76 & 21 & 84 & 40 & 80 \\
\hline$(-)$ & 6 & 24 & 4 & 16 & 10 & 20 \\
\hline \multicolumn{7}{|l|}{ Deviasi Septum : } \\
\hline$(+)$ & 9 & 36 & 8 & 32 & 17 & 34 \\
\hline$(-)$ & 16 & 64 & 17 & 68 & 33 & 66 \\
\hline \multicolumn{7}{|l|}{ Krusta : } \\
\hline$(+)$ & 1 & 4 & 1 & 4 & 2 & 4 \\
\hline$(-)$ & 24 & 96 & 24 & 96 & 48 & 96 \\
\hline Total & 25 & 100 & 25 & 100 & 50 & 100 \\
\hline
\end{tabular}

Keterangan : KND = kavum nasi dekstra, KNS = kavum nasi sisntra

Tabel 6 menunjukkan hasil pemeriksaan nasoendoskopi pada 25 pasien dengan temuan kavum nasi yang sempit 33 kasus (66\%), konka inferior eutrofi 23 kasus (46\%), warna konka inferior merah muda 39 kasus (78\%), konka media eutrofi 32 kasus (64\%), meatus media terbuka 30 kasus (60\%), sekret positif 40 kasus (80\%), tidak ada deviasi septum 33 kasus (66\%), dan tidak ada krusta 48 kasus (96\%).

\section{PEMBAHASAN}

Berdasarkan penelitian mengenai profil pasien rinosinusitis kronik di Poliklinik THT-KL RSUP Dr.M.Djamil Padang periode 1 Januari - 31 Desember 2012 terdapat 63 kasus rinosinusitis kronik. Kasus rinosinusitis kronik paling banyak terjadi pada kelompok usia muda dan dewasa, yaitu sebanyak 39 pasien $(61,90 \%)$. Hal ini sejalan dengan penelitian yang dilakukan oleh sub-bagian Rinologi Departemen THT-KL FK-UI/RSCM bahwa prevalensi sinusitis tertinggi pada usia dewasa 18-75 tahun. Berdasarkan penelitian di Amerika Serikat, prevalensi pasien rinosinusitis kronis meningkat seiring dengan peningkatan usia yang mana $2,7 \%$ terjadi pada kelompok usia 20 - 29 tahun dan 6,6\% terjadi pada kelompok usia 50 - 59 tahun. Setelah usia 60 tahun, prevalensi ini mengalami penurunan sebanyak 4,7\%. Ada dugaan bahwa tingginya kasus rinosinusitis kronik pada usia dewasa disebabkan oleh aktivitas sosial yang banyak dilakukan di luar rumah sehingga berisiko terpapar polutan atmosfer, virus, dan bakteri. $5,7,8$

Kasus rinosinusitis kronik lebih banyak terjadi pada perempuan dibandingkan laki - laki, yaitu sebanyak 38 pasien $(60,32 \%)$. Perbandingan kasus rinosinusitis kronik pada laki - laki dan perempuan didapatkan sebesar 3,9:6. Hal ini sama dengan penelitian di Amerika serikat bahwa kasus rinosinusitis kronik banyak terjadi pada perempuan dengan perbandingan antara perempuan dan laki - laki adalah $6: 4$. Ada dugaan bahwa penyakit rinosinusitis kronik banyak diderita oleh wanita karena wanita lebih sering mengalami ISPA, tetapi teori ini masih belum diketahui secara jelas. ${ }^{4,5}$

Berdasarkan penelitian, kasus rino-sinusitis kronik banyak disebabkan oleh deviasi septum, yaitu sebanyak 26 kasus $(41,27 \%)$. Sedangkan kasus rinosinusitis kronik yang disebabkan oleh hipertrofi adenoid hanya sekitar 2 kasus (3,17\%). Pada penelitian yang dilakukan oleh Santoso pada tahun 2007, faktor deviasi septum merupakan faktor nomor 
dua terbanyak yang menyebabkan terjadinya rinosinusitis kronik, yaitu sebanyak 27 kasus (51,92\%) yang diambil dari 52 sampel. Selain itu, faktor variasi anatomi pada kavum nasi dapat menyebabkan terjadinya obstruksi pada KOM dan mengganggu pembersihan mukosilia sehingga memungkinkan terjadinya infeksi pada sinus. ${ }^{9}$

Dari penelitian yang telah dilakukan, gejala klinik yang paling banyak dirasakan oleh pasien rinosinusitis kronik adalah hidung tersumbat, yaitu sebanyak 56 kasus $(88,89 \%)$ dan diikuti oleh gejala lain, seperti pilek $(71,43 \%)$ serta ingus di tenggorok $(68,25 \%)$. Beberapa gejala klinik yang terbanyak tersebut merupakan kriteria mayor dari gejala rinosinusitis kronik. Keadaan ini sesuai dengan definisi rinosinusitis kronik berdasarkan EPOS, yaitu inflamasi mukosa hidung dan sinus paranasal yang ditandai dengan adanya dua atau lebih gejala, salah satunya termasuk hidung tersumbat atau pilek (sekret hidung anterior / posterior) dan dapat disertai adanya nyeri wajah atau rasa tertekan di wajah dan penurunan atau hilangnya penghidu. Berdasarkan penelitian Amaruddin dkk pada tahun 2005, terhadap 22 sampel didapatkan gejala klinik rinosinusitis kronik paling banyak adalah hidung tersumbat (100\%), kemudian diikuti dengan gejala lain, seperti ingus purulen $(95,5 \%)$ dan nyeri pada wajah $(91 \%) .7,8,10$

Berdasarkan pemeriksaan rinoskopi anterior yang dilakukan pada 63 pasien rinosinusitis kronik didapatkan hasil paling banyak yaitu kavum nasi sempit (74,60\%), konka inferior tampak udem $(49,21 \%)$, konka media sukar dinilai $(43,65 \%)$, tampak sekret di kavum nasi $(76,19 \%)$, dan tidak ada deviasi septum (64,29\%). Menurut Sunaryanto pada penelitiannya tahun 2008, dari pemeriksaan rinoskopi anterior akan ditemukan kavum nasi sempit, konka inferior tampak udem, dan ditemukan sekret mukopurulen pada meatus media. ${ }^{11}$

Berdasarkan pemeriksaan naso-endoskopi pada yang dilakukan pada 25 pasien rinosinusitis kronik didapatkan hasil paling banyak yaitu kavum nasi sempit (66\%), konka inferior tampak eutrofi (46\%), warna konka inferior tampak merah muda (78\%), konka media eutrofi (64\%), meatus media terbuka (60\%), terlihat sekret di kavum nasi (80\%), tidak ditemukan adanya deviasi septum (66\%), dan tidak ada krusta (96\%). Menurut Becker jika pada pemeriksaan nasoendoskopi ditemukan udem, hiperemis, krusta, polip, dan sekret purulen di kavum nasi dapat didiagnosis sebagai rinosinusitis kronik. Keadaan ini sesuai dengan definisi rinosinusitis berdasarkan EPOS, yaitu salah satu penemuan pada pemeriksaan nasoendoskopi berupa polip, sekret mukopurulen dari meatus media, dan/atau udem mukosa di meatus media. Berdasarkan hasil pemeriksaan nasoendoskopi pada pasien rinosinusitis kronik, hanya 25 pasien yang dilakukan pemeriksaan nasoendoskopi. Hal ini disebabkan oleh beberapa faktor, seperti pasien yang menolak untuk dilakukan pemeriksaan nasoendoskopi dan faktor biaya. ${ }^{2,5}$

\section{KESIMPULAN}

Kelompok usia terbanyak pasien rinosinusitis kronik adalah kelompok usia muda dan dewasa, yaitu sebesar $61,90 \%$.

Rinosinusitis kronik lebih sering terjadi pada perempuan, yaitu sebanyak $60,32 \%$ dengan perbandingan perempuan dan laki-laki $6: 3,9$.

Tanda dan gejala yang ditemukan pada rinosinusitis kronik terbanyak adalah deviasi septum, yaitu sebanyak $41,27 \%$.

Gejala klinik rinosinusitis kronik yang terbanyak ditemukan adalah hidung tersumbat, yaitu sebanyak $88,89 \%$.

Pada pemeriksaan rinoskopi anterior yang terbanyak ditemukan adalah kavum nasi sempit (74,60\%), konka inferior tampak udem (49,21\%), konka media sukar dinilai (43,65\%), tampak sekret di kavum nasi $(76,19 \%)$, dan tidak ada deviasi septum (64,29\%).

Pada pemeriksaan nasoendoskopi yang terbanyak ditemukan adalah kavum nasi sempit (66\%), konka inferior eutrofi (46\%), warna konka inferior tampak merah muda (78\%), konka media eutrofi (64\%), meatus media terbuka (60\%), tampak sekret di kavum nasi (80\%), tidak ada deviasi septum (66\%), dan tidak ada krusta (96\%).

\section{DAFTAR PUSTAKA}

1. Beninger MS. Adult chronic rhinosinusitis definition, diagnosis, epidemiology, pathophysiology. Otolaryngol Head and Neck Surgery. Michigan. 2003. 
2. Helm Steve, Miller AL. Natural treatment of chronic rhinosinusitis. Dalam Alternative Medicine Review. 2006; $11(3): 196-207$.

3. Mangunkusumo E, Nusjirwan R. Sinusitis. Dalam: Nurbaiti Iskandar, Efiaty AS ed Buku Ajar IImu Kesehatan Telinga Hidung Tenggorok Kepala Leher. Edisi ke-5. Jakarta : Balai Penerbit FKUI; 2004.

4. Brook, Itzhak. Sinusitis From microbiology to management. Georgetown University School of Medicine Washington. D.C. USA. 2006.

5. Fokkens W, Lund V. European position on rhinosinusitis and nasal polyps. Rhinology. Department of Otolarhinolaryngology. Amsterdam. 2012.

6. Hamilos, Daniel L. chronic rhino-sinusitis : epidemiology and medical management. Dalam Clinical Reviews in Allergy and Immunology. Boston. 2011.
7. Becker, Daniel G. Sinusitis. Dalam: Otorhinolaryngology-Head and Neck Surgery. University of Pennsylvania Hospital. Philadelphia. USA. 2003.

8. Mangunkusumo E, Soetjipto D. Sinus Paranasal. Dalam: Nurbaiti Iskandar, Efiaty AS editor. Buku Ajar IImu Kesehatan Telinga Hidung Tenggorok Kepala Leher. Edisi ke-5. Jakarta: Balai Penerbit FKUI; 2004.

9. Santoso B. Variasi anatomi pada rinosinusitis maksilaris kronik di RSUP Dr.Sardjito. Bagian IImu Kesehatan THT-KL RSUP Dr.Sardjito. Yogyakarta. 2007.

10. Amaruddin. Hubungan antara derajat rinosinusitis berdasarkan gejala dan CT-Scan. Artikel Penelitian Bagian IImu Kesehatan THT-KL FK UGM/RS Dr.Sardjito. Yogyakarta. 2005.

11. Sunaryanto A. Sinusitis maksilaris pada dewasa. Kepaniteraan Klinik Madya IImu THT FK Universitas Udayana. Bali. 2008. 